\title{
PERANCANGAN SISTEM INFORMASI PEMBANGUNAN DAN RENOVASI HUNIAN PADA KUNTORO KONTRAKTOR BERBASIS JAVA
}

\author{
M.Syahlan Eka Putra \\ Program Studi Teknik Informatika, Fakultas Teknik dan Ilmu Komputer, \\ Universitas Indraprasta PGRI \\ Jalan Raya Tengah No 80, Kelurahan Gedong, Pasar Rebo, Jakarta Timur \\ syahlaneka27@gmail.com
}

\begin{abstract}
Abstrak
Pada saat ini perkembangan teknologi di bidang informasi mengalami kemajuan yang sangat pesat. Teknologi informasi menjadi sarana yang penting dalam kehidupan manusia seperti halnya dalam manajemen pengolahan data proyek yang dapat menggunakan sistem komputerisasi. Kuntoro Kontraktor merupakan salah satu penyedia jasa pembangunan dan renovasi hunian yang bertempat di Kalibata Pulo, Pancoran, Jakarta Selatan ini sudah biasa menangani berbagai proyek hunian seperti pembangunan dan renovasi rumah, kontrakan, kos-kosan dan lainnya. Saat ini proses bisnis yang dilakukan masih sederhana dan masih kesulitan dalam menangani pengolahan data secara keseluruhan. Berdasarkan permasalahan tersebut, maka peneliti melakukan penelitian dengan metode grounded research untuk merancang dan membuat suatu Sistem Informasi Pembangunan dan Renovasi Hunian yang menggunakan bahasa pemrograman Java dan terintegrasi dengan database MySQL.
\end{abstract}

Kata Kunci: Sistem Informasi Pembangunan, Renovasi, Hunian, Java, MySQL

\section{Abstract}

At this time the development of technology in the field of information is experiencing very rapid progress. Information technology becomes an important means in human life as it is in the management of project data processing that can use computerized systems. Kuntoro Kontraktor is one of the providers of residential development and renovation services located in Kalibata Pulo, Pancoran, South Jakarta is used to handle various residential projects such as house construction and renovation, rent, boarding and others. Currently the business process carried out is still simple and still has difficulty in handling data processing as a whole. Based on these problems, the researcher conducted research with grounded research methods to design and create a Residential Development and Renovation Information System that uses the Java programming language and integrates with MySQL databases.

Keywords: Construction Information System, Renovation, Residential, Java, MySQL

\section{PENDAHULUAN}

Perkembangan teknologi informasi kini sudah mulai digunakan di berbagai bidang kehidupan, salah satunya dalam bidang bisnis. Banyak terdapat berbagai macam bidang bisnis yang ada di Indonesia salah satunya yaitu bisnis dalam bidang konstruksi bangunan, dimana dalam bisnis ini diperlukan penggunaan sistem informasi dalam pengolahan data proyek konstruksi bangunan yang sedang dikerjakan.

Kuntoro Kontraktor merupakan salah satu penyedia jasa pembangunan dan renovasi hunian yang bertempat di Kalibata Pulo, Pancoran, Jakarta Selatan ini sudah biasa menangani berbagai proyek hunian seperti pembangunan dan renovasi rumah, kontrakan, kos-kosan dan lainnya. Saat ini proses bisnis yang dilakukan masih sederhana dan masih kesulitan dalam menangani pengolahan data secara keseluruhan. Berdasarkan permasalahan diatas, maka peneliti melakukan penelitian dengan judul "Perancangan Sistem Informasi Pembangunan dan Renovasi Hunian pada Kuntoro Kontraktor Berbasis Java".

Perancangan adalah proses pengembangan spesifikasi baru berdasarkan hasil analisis sistem (Subhan, 2012). Muhamad Muslihudin dan Oktafianto (2016) berpendapat bahwa sistem adalah sekumpulan komponen atau jaringan kerja dari prosedur-prosedur yang saling berkaitan dan bekerja sama untuk mencapai sasaran atau tujuan tertentu. Menurut Sutarman (2012) memberikan pengertian informasi sebagai sekumpulan fakta (data) yang diorganisasikan dengan cara tertentu sehingga mereka mempunyai arti bagi si penerima. Pembangunan merupakan suatu proses 
perubahan yang dilakukan secara sadar dan terus menerus untuk mencapai kemajuan dan perbaikan hidup yang lebih baik menuju tujuan yang diinginkan (Suryono, 2010). Menurut Prasasti dalam Hardiana, Dharmayanti, dan Budiwati (2018) mengemukakan dalam jurnalnya bahwa, renovasi merupakan kegiatan yang dilakukan untuk memperbarui, memperbaiki, atau mengganti sebagian bangunan eksisting untuk mencapai kondisi yang lebih baik. Menurut Monks, dkk dalam Indriyani (2014), mengemukakan mengenai hunian atau tempat tinggal yang merupakan keberadaan seseorang di dalam suatu tempat dan lingkungan di mana mereka hidup dan bertempat tinggal dalam jangka waktu lama.

Tujuan dari penelitian ini untuk merancang sistem informasi pembangunan dan renovasi hunian guna menunjang pengelolaan data proyek pada Kuntoro Kontraktor dan menerapkan sebuah sistem informasi pembangunan dan renovasi hunian pada Kuntoro Kontraktor yang terkomputerisasi berbasis Java.

\section{PENELITIAN RELEVAN}

Penelitian yang dilakukan oleh (Somya, 2018) dengan judul Aplikasi Manajemen Proyek Berbasis Framework CodeIgniter dan Bootstrap di PT. Pura Barutama dengan tujuan untuk mengembangkan sistem aplikasi manajemen proyek yang dapat membantu perencanaan, melakukan pengawasan proyek, memberikan data laporan secara real-time, dan sebagai sarana informasi bagi para pemangku kepentingan. Dengan dilakukannya penelitian ini maka hasil yang didapat yaitu aplikasi manajamen proyek dapat mempermudah dan mempercepat unit-unit untuk melakukan request pembuatan memo pembangunan gedung baru atau renovasi gedung.

Penelitian yang dilakukan oleh (Wijoyo \& Hermanto, 2020) dengan judul Analisis Dan Perancangan Sistem Informasi Inventory Pada PT. Insan Data Permata dengan tujuan untuk merancang sistem inventory pada PT. Insan Data Permata yang nantinya dapat diakses setiap saat dan menyajikan informasi yang cepat, sehingga dapat menyajikan sajian informasi yang terarah. Dengan dibuatnya Analisis dan Perancangan Sistem Informasi Inventory pada PT. Insan Data Permata. semua kegiatan yang berhubungan dengan pendaftaran pelanggan, pengolahan barang, pengolahan transaksi pengadaan barang, penjualan barang dan laporan tidak lagi secara manual serta metode kualitatif yaitu metode penelitian tentang riset yang bersifat cenderung menggunakan analisis.

Penelitian yang dilakukan oleh (Yudharana et al., 2017) berjudul Perancangan Aplikasi Berbasis Android Untuk Manajemen Proyek Pembangunan Kapal Baru mempunyai tujuan untuk membangun sebuah aplikasi manajemen proyek pembangunan kapal baru berbasis android diharapkan pada akhirnya dapat membantu dalam memanajemen proyek pembangunan kapal melalui alat (tool) berupa aplikasi android untuk mengontrol, penjadwalan, sumber daya manusia dan kualitas proyek. Dengan dilakukannya penelitian ini maka hasil yang didapat yaitu membantu pihak galangan untuk memudahkan dan membantu mengelola manajemen proyek pembangunan kapal baru khususnya seorang manager proyek $(P M)$ dalam memanajemen proyek pembangunan kapal melalui alat (tool) berupa aplikasi android untuk mengontrol, penjadwalan, sumber daya manusia dan kualitas proyek

\section{METODE PENELITIAN}

Dalam melakukan penelitian senantiasa dilakukan suatu metode penelitian yang sesuai pokok permasalahan yang akan diteliti. Dalam hal ini peneliti menggunakan metode kualitatif Grounded Research, dimana menurut Warul Walidin, Saifullah dan Tabrani (2015), menjelaskan dalam bukunya yang berjudul Metodologi Penelitian Kualitatif \& Grounded Theory bahwa, Grounded Research merupakan prosedur penelitian kualitatif yang sistematik, di mana peneliti suatu teori yang menerangkan konsep, proses, tindakan, atau interaksi mengenai suatu topik pada level konseptual yang luas. Metode pengumpulan data yang dilakukan oleh peneliti untuk mendapatkan data-data serta informasi untuk mendukung penyempurnaan hasil dari penelitian ini antara lain :

\section{Observasi}

Metode observasi ini dilakukan dengan cara melakukan pengamatan secara langsung ke lapangan mengenai proses pembuatan laporan yang masih menyulitkan dalam pencarian data proyek, harga material dan perincian biaya sehingga dapat diketahui permasalahan dari objek yang diteliti. 
2. Wawancara

Peneliti mengajukan beberapa pertanyaan kepada salah satu penyedia jasa pembangunan dan renovasi hunian yaitu Bapak Kuntoro tentang sistem yang saat ini menjadi kelemahan dari bisnis tersebut, yang membuat pekerjaan menjadi tidak efektif dan efisien, sehingga diperoleh data yang akurat dan sesuai dengan sistem yang berjalan.

3. Studi Pustaka

Data yang diperoleh melalui studi kepustakaan adalah sumber informasi yang telah ditemukan oleh para ahli yang kompeten dibidangnya masing-masing sehingga relevan dengan pembahasan yang sedang diteliti.

Adapun langkah-langkah pengembangan sistem dalam penyusunan tugas akhir ini sebagai berikut :

1. Tahap Analisis Kebutuhan

2. Tahap Sistem Desain

3. Tahap Perancangan Sistem

4. Tahap Penerapan atau Penggujian Program

5. Implementasi dan Pemeliharaan Sistem

\section{HASIL DAN PEMBAHASAN}

\section{Analisis Permasalahan}

Berdasarkan pengamatan peneliti terhadap sistem informasi yang saat ini digunakan oleh Kuntoro Kontraktor dapat diambil kesimpulan, bahwa terdapat beberapa masalah antara lain seperti pengolahan data konsumen pada Kuntoro Kontraktor masih bersifat manual, pengolahan data penggajian tukang pada Kuntoro Kontraktor masih bersifat manual, kesulitan dalam mencari data proyek pada Kuntoro Kontraktor, dan sering hilangnya data proyek pada Kuntoro Kontraktor.

\section{Alternatif Penyelesaian Masalah}

Setelah menganalisa permasalahan yang terjadi dapat peneliti sebutkan alternatif penyelesaian masalah antara lain seperti Merancang sistem informasi pembangunan dan renovasi hunian guna menunjang pengelolaan data proyek pada Kuntoro Kontraktor dan menerapkan sebuah sistem informasi pembangunan dan renovasi hunian pada Kuntoro Kontraktor yang terkomputerisasi berbasis Java.

\section{Diagram Konteks}

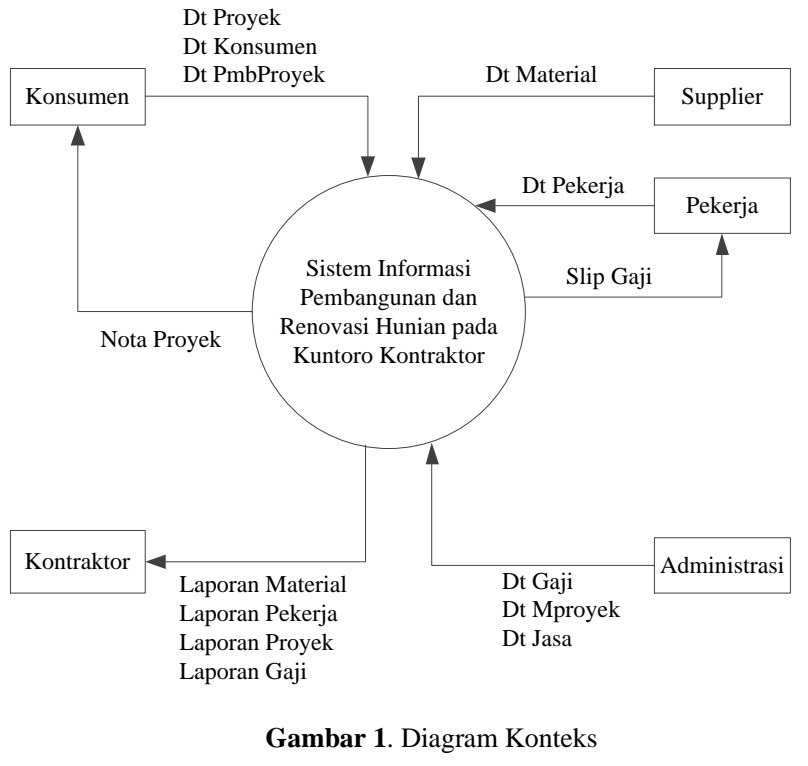

Diagram Konteks menggambarkan keseluruhan sistem secara garis besar dimana dalam sistem informasi tersebut terdapat beberapa arus data seperti Dt Proyek, Dt Konsumen, Dt PmbProyek, Dt 
Material, Dt Pekerja, Dt Gaji, Dt Mproyek, Dt Jasa, Nota Proyek, Slip Gaji, Laporan Material, Laporan Pekerja, Laporan Proyek, Laporan Gaji

\section{Diagram Nol}

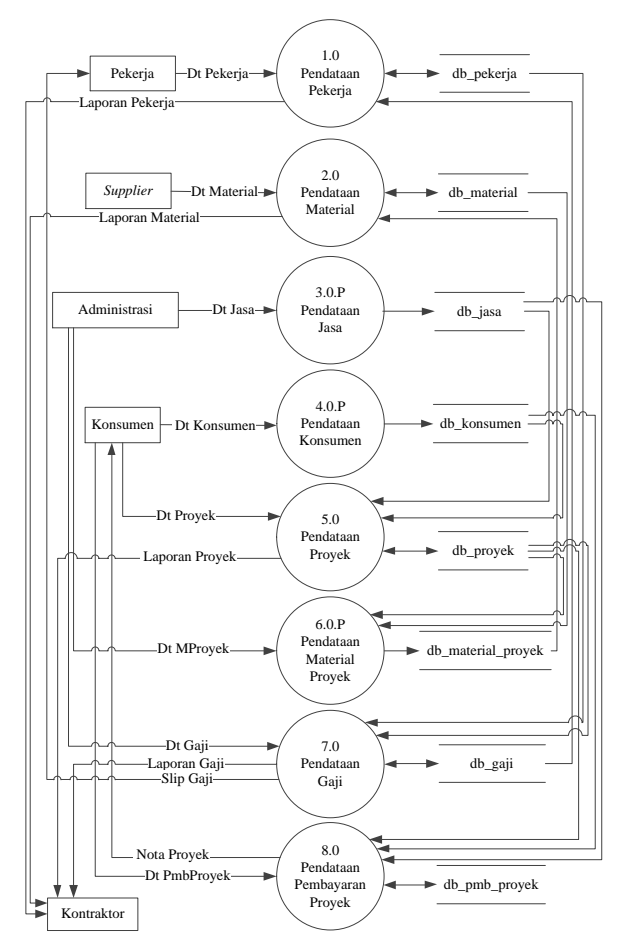

Gambar 2 Diagram Nol

Dalam hal ini diagram nol menggambarkan alur proses yang terdapat pada program yang peneliti buat, seperti proses pendataan pekerja, pendataan material, pendataan jasa, pendataan konsumen, pendataan proyek, pendataan material proyek, pendataan gaji, dan pembayaran proyek

\section{Entity Relationship Diagram (ERD)}

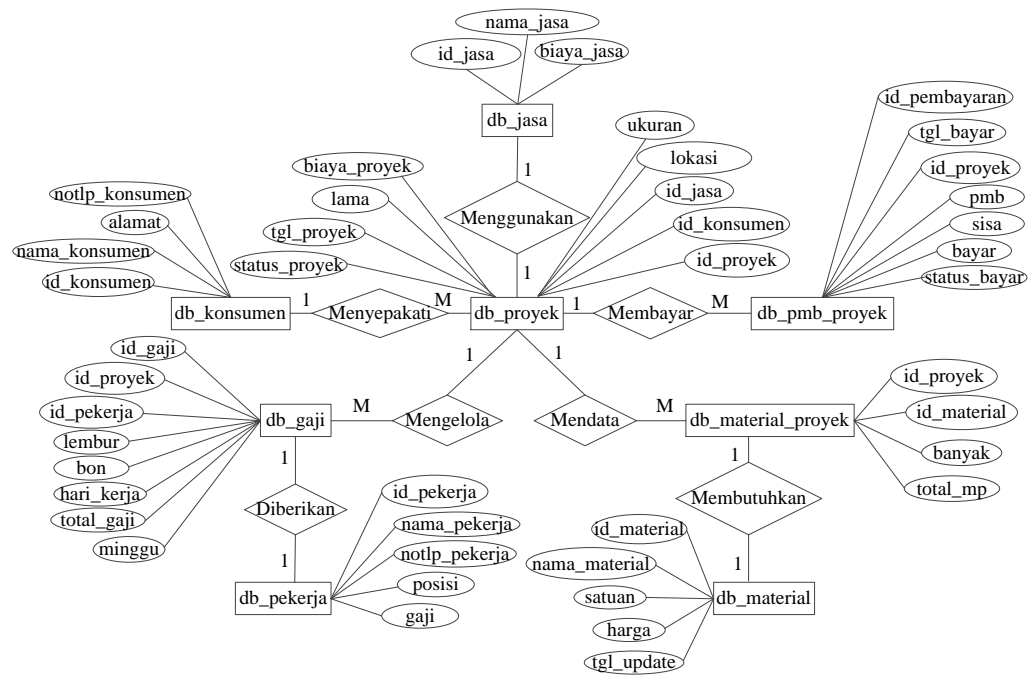

Gambar 3 Entity Relationship Diagram (ERD)

ERD yang tergambar pada jurnal ini menjelaskan tentang hubungan antar tabel pada basis data yang terdapat pada program, dimana dalam db_proyek membutuhkan data id_jasa pada tabel db_jasa, id_konsumen dari db_konsumen, sedangkan db_gaji membutuhkan data id_pekerja dari 
db_pekerja, data id_proyek dari db_proyek, dan kemudian db_material_proyek membutuhkan data id_material dari db_material, dan id_proyek dari db_proyek, lalu untuk db_pmb_proyek membutuhkan data id_proyek dari db_proyek

\section{Tampilan Layar Sistem}

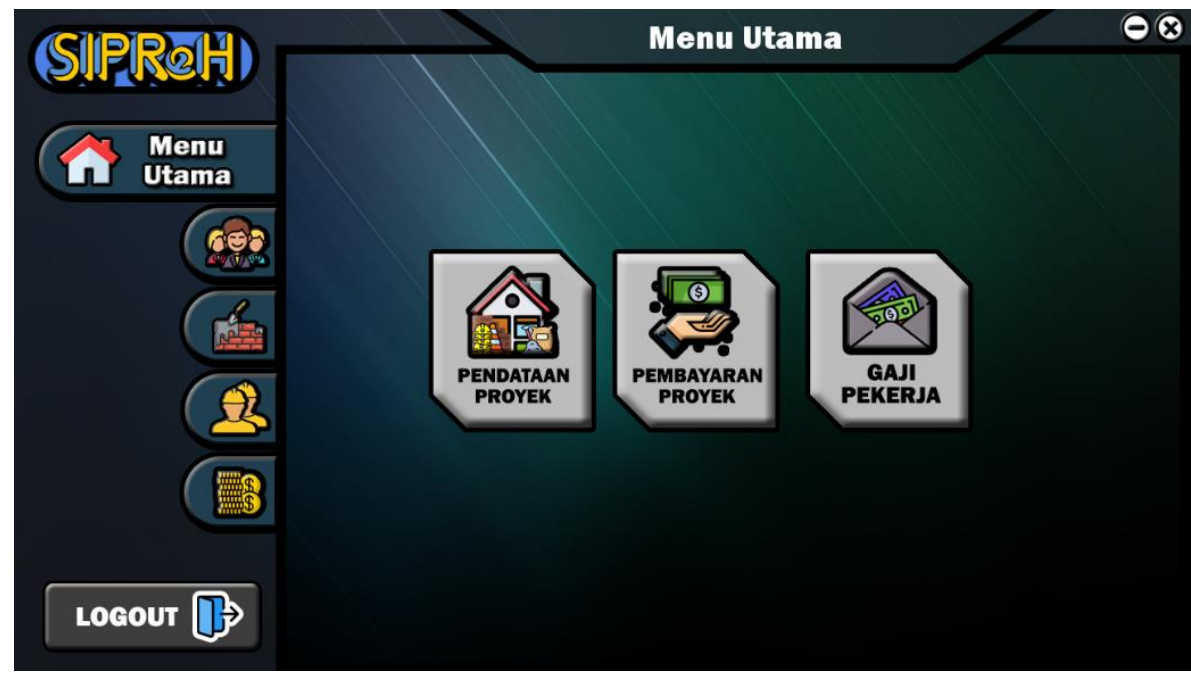

Gambar 4 Tapilan Menu Utama

Pada tampilan ini terdapat navigasi yang berfungsi untuk menuju form-form yang ada pada program ini, dimana di bagian sidebar terdapat beberapa menu yang apabila di klik maka akan menuju ke form master sedangkan di bagian tengahnya terdapat menu yang menuju ke form transaksi..

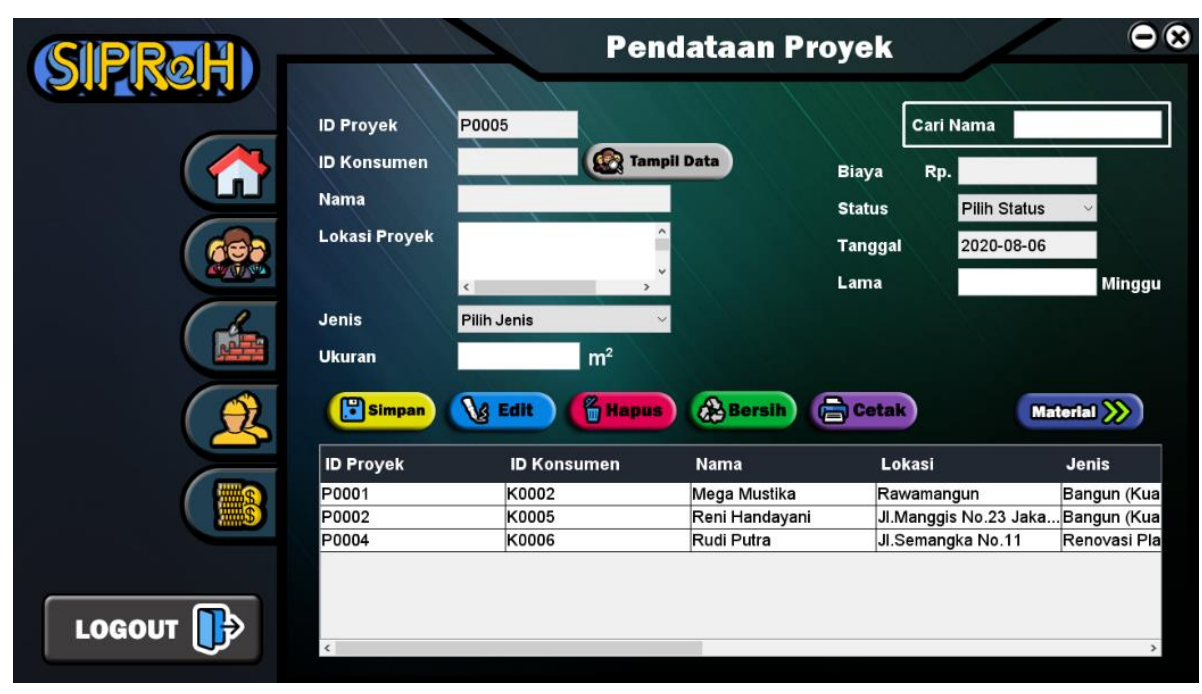

Gambar 5 Tampilan form Pendataan Proyek

Tampilan ini digunakan untuk meng-input data proyek yang dipesan oleh konsumen terdiri dari identitas konsumen, lokasi tempat yang akan dibangun, jenis jasa yang dipilih, dan data yang diperlukan untuk proyek. 


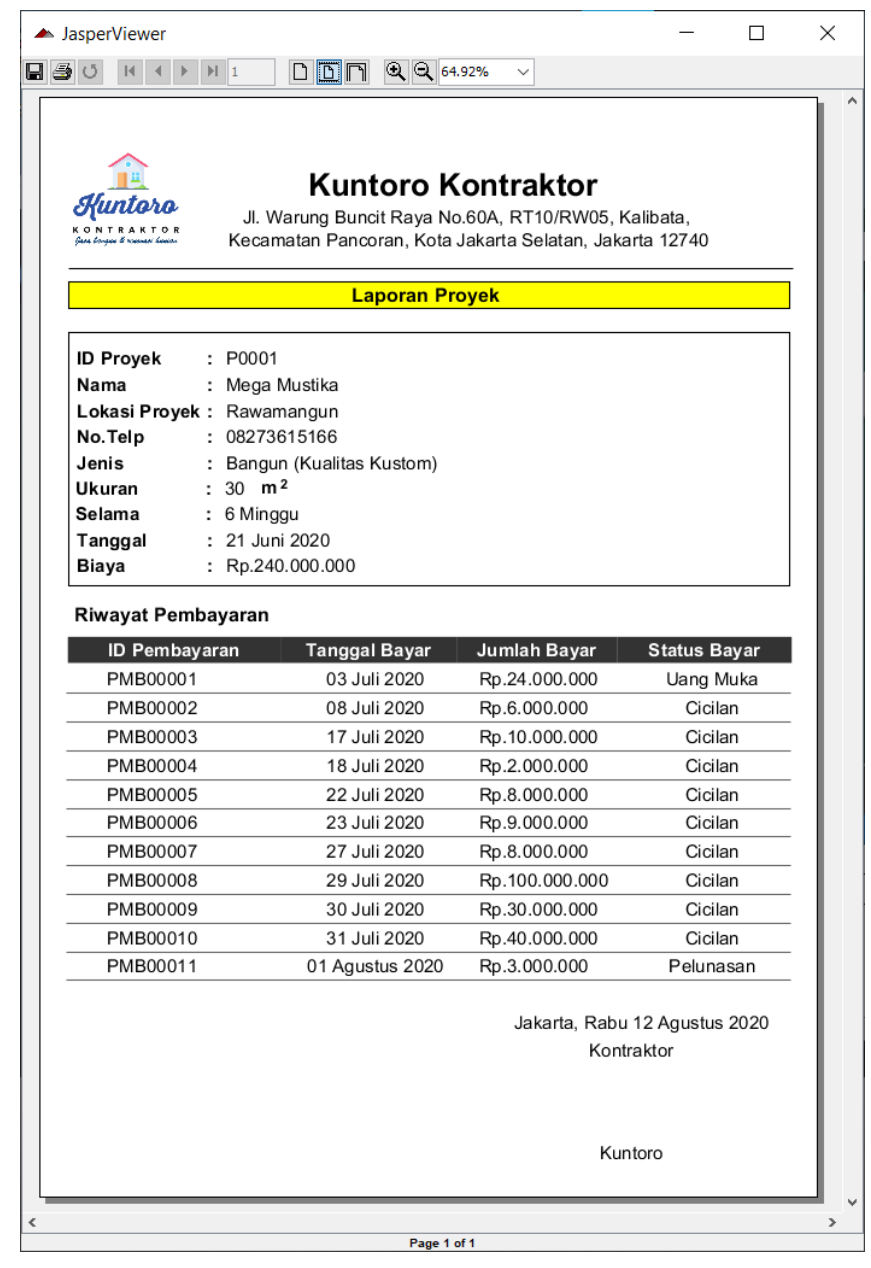

Gambar 6 Tampilan Laporan Proyek

Tampilan ini merupakan tampilan laporan data proyek yang berisikan tentang informasi dari konsumen, data proyek dan riwayat pembayaran yang dilakukan oleh konsumen yang kemudian dilaporkan kepada atasan.

\section{Jaringan Semantik Tampilan Layar}

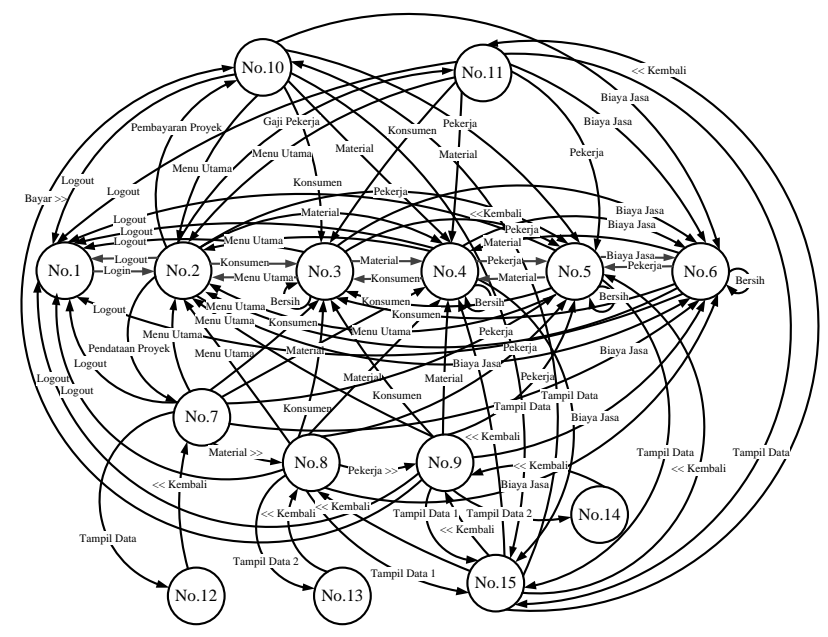

Gambar 7 Jaringan Semantik Tampilan Layar 
Jaringan Semantik Tampilan menggambarkan bagaimana masing-masing tampilan terhubung ketika sebuah tindakan untuk menekan tombol ataupun navigasi yang terdapat dalam program, yang dimana akan memberitahu program untuk berpindah tampilan, misalnya ketika dalam form pendataan proyek melakukan aksi menekan tombol konsumen pada navigasi, maka program akan melakukan proses untuk berpindah halaman, yang semula berada pada halaman pendataan proyek kemudian berpindah ke halaman konsumen.

\section{SIMPULAN}

Berdasarkan penelitian yang telah peneliti lakukan dengan judul "Perancangan Sistem Informasi Pembangunan dan Renovasi Hunian pada Kuntoro Kontraktor Berbasis Java". Maka peneliti dapat mengambil beberapa simpulan, yaitu sebagai berikut :

1. Sistem informasi pembangunan dan renovasi hunian pada kuntoro kontraktor berbasis java, dapat mengatasi masalah yang sering timbul akibat sistem yang masih bersifat manual. Sistem ini dapat membuat pengelolaan data proyek menjadi lebih efektif dan efisien, sehingga dapat lebih mempermudah pihak pengelola dalam menyimpan data yang diperlukan untuk keperluan proyek.

2. Sistem informasi pembangunan dan renovasi hunian yang peneliti buat dapat meminimalisir masalah kehilangan data dan kekeliruan data yang terkait dengan harga material, gaji pekerja, biaya jasa, dan kebutuhan proyek yang diperlukan, dikarenakan sistem informasi pembangunan dan renovasi hunian yang peneliti buat terintegrasi dengan database MySQL sehingga data yang sudah ter-input akan tersimpan ke dalam sistem database tersebut dan memudahkan dalam pencarian serta pengelolaan terkait dengan proyek yang dikerjakan.

3. Sistem informasi pembangunan dan renovasi hunian yang peneliti buat dapat mempermudah pengelolaan data proyek dikarenakan adanya fitur pembuatan laporan berdasarkan proyek yang sedang berlangsung, sehingga pengguna tidak perlu lagi untuk membuat laporan terkait proyek yang sedang berlangsung seperti laporan material, laporan pekerja, laporan gaji, laporan proyek, nota proyek, dan juga slip gaji. Hal ini dapat menghemat waktu dan meningkatkan efisiensi pengelolaan laporan proyek serta membantu pengguna untuk mengelola data proyek dengan lebih baik lagi.

\section{DAFTAR PUSTAKA}

Hardiana, I. C., Dharmayanti, C., \& Budiwati, I. A. M. (2018). Pengaruh Risiko Pada Proyek Perluasan Dan Renovasi Hotel Di the Effect of Risks on Hotel Extention and Renovation Projects in Bali Towards the Cost, Quality, and Time of Project. 6(1), 65-74. http://ojs.unud.ac.id/index.php/jsn/index

Indriyani, S., Mabruri, M. I., \& Purwanto, E. (2014). Developmental and Clinical Psychology SUBJECTIVE WELLBEING Pada Lansia Ditinjau Dari Tempat Tinggal. Developmental and Clinical Psychology, 3(1), 66-72. http://journal.unnes.ac.id/sju/index.php/dcp

Muhammad, M., \& Oktafianto. (2016). Analisis dan Perancangan Sistem Informasi Menggunakan Model Terstruktur dan UML. CV. Andi Offset.

Somya, R. (2018). Aplikasi Manajemen Proyek Berbasis Framework CodeIgniter dan Bootstrap di PT. Pura Barutama. Jurnal Informatika: Jurnal Pengembangan IT, 3(2), 143-150. https://doi.org/10.30591/jpit.v3i2.726

Subhan, M. (2012). Analisis Perancangan Sistem. Lentera Ilmu Cendikia.

Suryono, A. (2010). Dimensi-Dimensi Prima Teori Pembangunan. UB Press.

Sutarman. (2012). Buku Pengantar Teknologi. Bumi Aksara.

Walidin, W., Idris, S., \& Tabrani ZA. (2015). Metodologi Penelitian Kualitatif \& Grounded Theory. FTK Ar-Raniry Press.

Wijoyo, A. C., \& Hermanto, D. (2020). Analisis dan Perancangan Sistem Informasi Inventory pada PT Insan Data Permata. Jurnal Riset Dan Aplikasi Mahasiswa Informatika (JRAMI), 1(02), 165-170. https://doi.org/10.30998/jrami.v1i02.231

Yudharana, L., Pribadi, T. W., \& Arif, M. S. (2017). Perancangan Aplikasi Berbasis Android Untuk Manajemen Proyek Pembangunan Kapal Baru. Jurnal Teknik ITS, 6(2), 2-7. https://doi.org/10.12962/j23373539.v6i2.25940 